\title{
Identification of Superior Fruits Commodities in North Sumatra Province
}

\author{
Desi Novita ${ }^{1, *}$, Teja Rinanda ${ }^{2}$, and Mhd. Ilham Riyadh ${ }^{1}$ \\ ${ }^{1}$ Department of Agribusiness, Universitas Islam Sumatera Utara 20217 Medan, Indonesia \\ ${ }^{2}$ Department of Management, STIE Graha Kirana, 20118 Medan, Indonesia
}

\begin{abstract}
Agricultural is a sector that provides the largest contribution to the economy in North Sumatra Province. The development of fruit production has decreased since 2015 . This study aims to identify superior fruits commodities, analyze the development of production for superior fruits commodities, and identify production centers of superior fruits commodities in North Sumatra Province. This study uses secondary data, Namely the time series 2015-2019 period. Data were obtained from the Food Crops and Horticulture Service and the Central Statistics Bureau of North Sumatra Province. The data analysis used is the Location Quotient (LQ) method. The results showed that seven superior fruits commodities were Water Apple (LQ 3.75), Salak (LQ 3.45), Siam Orange (LQ 3.28), Pineapple (LQ 1.58), Durian (LQ 1.35), Sawo (LQ 1.29), and Duku (LQ 1.13). The development of durian, Salak, Duku, and Sawo production shows an increase in the 2015-2019 period. Meanwhile, the development of water apple, Siam Orange, and Pineapple production has shown a decline in production in the 2015-2019 period. The main production centers for each of these superior fruits commodities include Binjai (Water Apple), South Tapanuli (Salak), Karo (Siam Orange). North Tapanuli (Pineapple), Dairi (Durian), South Nias (Duku), and Batubara (Sawo).
\end{abstract}

\section{Introduction}

The agriculture sector is a sector that has become a strategic part of people's lives in the North Sumatra Province. The agricultural sector plays a role as the main contributor in the formation of GRDP which reached $21.33 \%$ in 2020 [1]. In addition, the agricultural sector is also the sector that absorbs the highest workforce, produces export commodities, and supports the economy. This condition shows that agricultural commodities have the potential to be developed and play an important role in regional development in North Sumatra.

The horticulture sub-sector is one of the sub-sectors that have the potential to be developed. One of them is fruits commodities. Fruits commodities have high economic value. High added value and are a source of vitamins. The demand for fruits is growing worldwide [2]. Based on the FAO report, Indonesia is in fifth position as a world tropical fruits-producing country [3].

* Corresponding author: desi.novita@uisu.ac.id 
Meanwhile, the increasing demand for fruits has not been fully supported by domestic production. Indonesia still imports more fruits from abroad than exports locally produced products. Fruits are the commodities with the second-highest import value in Indonesia. Indonesian fruit imports increased by $9.26 \%$ in 2019 [4].

One of the provinces in Indonesia that has high fruit production compared to other regions is North Sumatra Province. The potential for high market opportunities and the potential for land resources that are still wide open must be accompanied by proper production management so that the comparative advantage of fruits is increasing. To increase the comparative advantage, appropriate development policies are needed. The first step in formulating development policies is to map out the superior fruits commodities in North Sumatra Province. Superior commodities are basic commodities produced by an excess area so that they can be sold outside the area [5]. By mapping the superior fruits commodities, it is hoped that they can formulate various policies in their management [6].

In addition, the determination of superior commodities in each region cannot be separated from adjustments to land suitability and other resource capabilities in the area so that they can provide added value and have an impact on increasing people's income. The determination of these superior commodities also considers their contribution to the economy and equity in the region. [7].

Based on this description, this study aims to identify superior fruits commodities, analyze the development of superior fruits production, and identify production centers for superior fruits commodities in North Sumatra.

\section{Research Methods}

This research was conducted in North Sumatra province. Research is quantitative research. The location determination was done deliberately because North Sumatra is one of the centers for developing fruits commodities. The data used in this research is secondary data. Secondary data is data generated by an organization and used by other people [8]. The data used is data on fruit production at the provincial level and in 33 districts/cities in north Sumatra province in the 2015-2019 period.

The analytical method used is the Location Quotient (LQ) method. The LQ method is a comparative analysis by determining the magnitude of the role of commodities in an area compared to the role of the commodities at a higher level. LQ aims to classify superior fruits commodities and production centers for superior fruit commodities in North Sumatra. The calculation of LQ is to apply the notations found in the LQ formula [9]. The LQ can show superior commodities based on the proportion of production in an area with a wider area [10]. In summary, the LQ formula can be written as follows:

Information:

$$
L Q=\frac{\text { Pik/Ptk }}{\text { Pip/Ptp }}
$$

LQ = Location Quotient

Pik = Production of fruit commodity $i$ at the district level

Ptk = Total fruit commodities production at the district level

Pip = Production of fruit commodity $\mathrm{i}$ at the provincial level

Ptp =Total fruit commodities production at the provincial level

The results of the calculation of the LQ value will produce 3 criteria, namely [11]:

LQ $>1$ means that the commodities become basic commodities that have a comparative advantage in a region. The results can meet the needs in the region and can be exported outside the region. 
$\mathrm{LQ}=1$ means that the commodities become non-basic commodities that do not have a comparative advantage in a region. The results can only meet the needs of the region.

LQ $<1$ means that the commodities become non-basic commodities that do not have a comparative advantage in a region. The result is not able to meet the needs in the region so it requires supplies from outside the region.

\section{Results and Discussion}

\subsection{Superior Fruits Commodities o in North Sumatra Province}

The average LQ value in general for fruit commodities is 1.13 . This value indicates that the fruit commodities in North Sumatra Province are superior commodities. Partially. the results showed that there were seven superior fruits commodities in North Sumatra Province including Water Apple (LQ 3.75), Salak (LQ 3.45), Siam Oranges (LQ 3.28), Pineapple (LQ 1.58), Durian (LQ 1.35), Sawo (LQ 1.29) and Duku (LQ 1.13). These seven commodities have a more meaningful role in the economy of North Sumatra. This is because North Sumatra Province has carried out trade activities outside the province for these seven commodities. The results of the LQ calculation are the results of the average LQ value in the 2015-2019 periods.

Table 1. LQ Calculation Results for 2015-2019

\begin{tabular}{|c|c|c|c|c|c|c|c|}
\hline \multirow[b]{2}{*}{ Commodities } & \multicolumn{5}{|c|}{ LQ } & \multirow[b]{2}{*}{ Average } & \multirow{2}{*}{$\begin{array}{r}\text { Base/ } \\
\text { Non Base }\end{array}$} \\
\hline & 2015 & 2016 & 2017 & 2018 & 2019 & & \\
\hline Avocado & 0.45 & 0.74 & 0.68 & 0.71 & 0.81 & 0.68 & Non Base \\
\hline Starfruit & 0.59 & 0.7 & 0.74 & 0.8 & 0.93 & 0.75 & Non-Base \\
\hline Duku & 0.73 & 0.95 & 1.56 & 1.15 & 1.25 & 1.13 & Base \\
\hline Durian & 0.95 & 1.62 & 1.32 & 1.33 & 1.55 & 1.35 & Base \\
\hline Guava & 0.65 & 0.77 & 0.8 & 0.91 & 0.71 & 0.77 & Non-Base \\
\hline Water Apple & 10.58 & 1.03 & 1.88 & 2.53 & 2.71 & 3.75 & Base \\
\hline Siamese Orange & 3.98 & 3.61 & 3.26 & 3.11 & 2.44 & 3.28 & Base \\
\hline Big Oranges & 0.38 & 1.1 & 2.25 & 0.23 & 0.22 & 0.84 & Non-Base \\
\hline Mango & 0.22 & 0.19 & 0.19 & 0.19 & 0.23 & 0.2 & Non-Base \\
\hline Mangosteen & 0.57 & 0.72 & 0.94 & 0.62 & 1.07 & 0.78 & Non-Base \\
\hline Jackfruit & 0.23 & 0.25 & 0.25 & 0.23 & 0.3 & 0.25 & Non-Base \\
\hline Pineapple & 1.86 & 1.86 & 1.45 & 1.48 & 1.27 & 1.58 & Base \\
\hline Papaya & 0.45 & 0.36 & 0.55 & 0.52 & 0.62 & 0.5 & Non-Base \\
\hline Banana & 0.28 & 0.32 & 0.35 & 0.3 & 0.32 & 0.31 & Non-Base \\
\hline Rambutan & 0.41 & 0.39 & 0.48 & 0.43 & 0.47 & 0.44 & Non-Base \\
\hline Salak & 2.87 & 2.68 & 2.76 & 3.97 & 4.95 & 3.45 & Base \\
\hline Sawo & 0.79 & 1.08 & 1.42 & 1.22 & 1.95 & 1.29 & Base \\
\hline Passion Fruit & 1.09 & 0.83 & 1.41 & 0.44 & 0.42 & 0.84 & Non-Base \\
\hline Soursop & 0.24 & 0.32 & 0.25 & 0.37 & 0.47 & 0.33 & Non-Base \\
\hline Breadfruit & 0.1 & 0.1 & 0.1 & 0.12 & 0.1 & 0.1 & Non-Base \\
\hline
\end{tabular}


Meanwhile, the commodity that is not included unseeded commodities with LQ value $<$ 1 are avocado, star fruit, guava, big orange, mango, mangosteen, jackfruit, papaya, banana, rambutan, passion fruit, and soursop. This means that these commodities have less role for the economy in North Sumatra Province. The value of LQ $<1$ indicates that the commodities are not categorized as superior commodities.

\subsection{Development of Production of Superior Fruits Commodities}

The development of the total production of superior fruits in North Sumatra Province has decreased by $6 \%$ per year. The total production of seven types of superior fruits in 2015 reached 1,053,720 tons, down to 808,142 tons in 2019. Production of Siam oranges and pineapples has decreased over the last 5 years. Meanwhile, the production of duku, durian, salak, and Sawo tends to increase.

The highest production of fruits during the last 5 years (2015-2019) is citrus fruit. The average citrus production is 416,845 tons/year. Then followed by Salak production (235,506 tons/year), pineapple Production (166,217 tons/year), durian (75,595 tons/year), guava (23,527 tons/year), duku (16,716 tons/year), and Sawo production $(10,342$ tons/year).

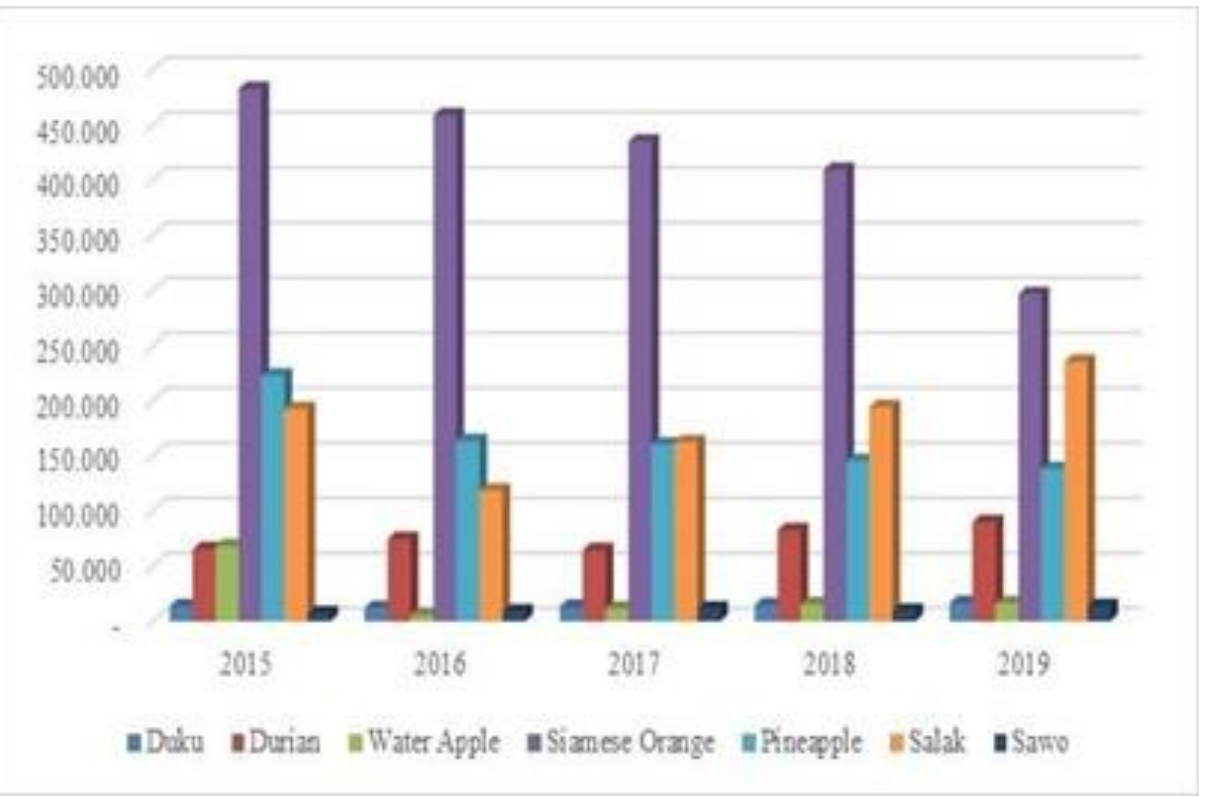

Fig. 1. Development of Leading Fruit Production

\subsection{Center for Production of Superior Fruit Commodities}

The results showed that the production centers of superior fruits commodities were in several districts/cities in North Sumatra Province. Six of the seven superior fruits commodity is produced from at least three districts in North Sumatra Province. Guava fruit, durian, and $d u k u$ are produced in $50 \%$ of districts/cities. 
Table 2. Distribution of Districts/Cities of ProductionCenters for Superior Fruits Commodities

\begin{tabular}{|c|c|c|c|}
\hline No & Commodities & $\begin{array}{l}\text { Number of } \\
\text { Center } \\
\text { Area }\end{array}$ & $\begin{array}{l}\text { Production Center Area of Superior Fruits Commodities } \\
\text { (LQ>1) }\end{array}$ \\
\hline 1 & Water Apple & 17 & $\begin{array}{l}\text { Binjai (LQ 15.3), North Labuhan Batu (LQ 13.46), Medan } \\
\text { (11.85), Asahan (LQ 8.71), Deli Serdang (LQ 4.55), South } \\
\text { Labuhan Batu (LQ 4.12), Pematangsiantar (LQ 4.51), } \\
\text { Tebing Tinggi (LQ 4.1), Serdang Bedagai (LQ 391.), } \\
\text { Langkat (LQ 355), Tanjung Balai (LQ 3.23), } \\
\text { Padangsidempuan, (LQ 2.41), Batubara (LQ 2.79), North } \\
\text { Padang Lawas (LQ 2.42), Labuhan Batu (LQ 2.22), South } \\
\text { Nias (LQ 1.14), and } \\
\text { Mandailing Natal (LQ 1.05) }\end{array}$ \\
\hline 2 & Salak & 3 & $\begin{array}{l}\text { South Tapanuli (LQ 5.37), Padangsidempuan (LQ 3.97) and } \\
\text { Humbang } \\
\text { Hasudutan (LQ 3.49), }\end{array}$ \\
\hline 3 & Siam Orange & 4 & $\begin{array}{l}\text { Simalungun (LQ 2.58), Karo (LQ 2.53), Southwest Phakpak } \\
\text { (LQ 2.45), } \\
\text { and Dairi (LQ 1.24) }\end{array}$ \\
\hline 4 & Pineapple & 1 & North Tapanuli (LQ 5.92) \\
\hline 5 & Durian & 16 & $\begin{array}{l}\text { Middle Tapanuli (LQ 10.91), Dairi (LQ 4.69), Gunung } \\
\text { Sitoli (LQ 4.69), Padang Lawas (LQ 3.33), North Labuhan } \\
\text { Batu (LQ 2.84), Mandailing Natal (LQ 2.64), Toba Samosir } \\
\text { (2.21), South Nias (LQ 2.04), Southwest Nias (LQ 1.93), } \\
\text { Nias (LQ 1.71), Humbang Hasudutan (LQ 1.69), Samosir } \\
\text { (LQ 1.83), Serdang Bedagai (LQ 1.70), South Labuhan } \\
\text { Batu } \\
\text { (LQ 1.47), North Nias (LQ 1.30), and Southwest Phakpak (LQ } \\
\text { 1.075) }\end{array}$ \\
\hline 6 & Sawo & 12 & $\begin{array}{l}\text { Batubara (LQ 16.6), Tebing tinggi (LQ 14.83), Binjai } \\
\text { (LQ 7.59), Tanjungbalai (LQ 6.96), Medan (LQ 5.18), } \\
\text { Pematangsiantar (LQ 3.87), South Labuhanbatu (LQ 3.26), } \\
\text { South Tapanuli (LQ 3.02), Padangsidempuan (LQ 2.19), } \\
\text { Langkat (LQ 2.05), Serdang Bedagai (LQ } \\
\text { 1. 60), and Deli Serdang (LQ 1.29). }\end{array}$ \\
\hline 7 & Duku & 19 & $\begin{array}{l}\text { South Nias (LQ 6.78), Deli Serdang (LQ 6.64), North Nias } \\
\text { (LQ 5.72), Serdang Bedagai (LQ 5.71), Padang Lawas (LQ } \\
\text { 5.01), Nias (LQ 4.68), Mandailing Natal (LQ 3.81), Middle } \\
\text { Tapanuli (LQ 3.38), South Labuhan Batu (LQ 3.23), } \\
\text { Labuhan Batu (LQ 3.16), Nias Barat (LQ 2.47), } \\
\text { Humbang Hasudutan (LQ 2.30), Norht Padang Lawas (LQ } \\
\text { 2.07), Dairi (LQ 1.60), Pematangsiantar (LQ 1.51), Toba } \\
\text { Samosir (LQ 1.51), North Labuhan Batu (LQ 1.12), Langkat } \\
\text { (LQ 1.20), and Asahan (LQ 1.13). }\end{array}$ \\
\hline
\end{tabular}




\section{Conclusions and Suggestions}

\subsection{Conclusions}

The results of the study concluded that the average LQ value for fruit commodities in North Sumatra Province is 1.13. This value means that fruit commodities are one of the commodities that can be seeded. The superior fruits commodities include water apple, Salak, Pineapple, Siam orange, Durian, Sawo, and Duku. The development of the total production of superior fruits commodities in North Sumatra Province decreased by $6 \%$ per year in the period 200115-2019. Production centers for superior fruits commodities are distributed in several districts/cities in North Sumatra Province.

\subsection{Suggestions}

Based on the research results, some things that are recommended are:

1. The government is expected to increase the land area and production of superior fruits commodities, especially in production centers.

2. Management of superior fruits commodities is expected to focus on the orientation of the needs of the market, especially exports.

3. Increasing promotions and campaigns for consuming local fruits to the community so that the superior commodities of these fruits can become their

Acknowledgments. The author would like to thanks the ministry of education, culture, research, and technology of Republic Indonesia for funding this research through PDUPT Schema in 2021.

\section{References}

1. BPS. 2021.North Sumatra in Figure 2020. Medan.Central Bureau of Statistics of North Sumatra Province.

2. A C. Adasme-Berrios et.al. 2015. Who are the potential consumers of organic fruits and vegetables in CentralChile? A CHAID Approach. FCA UNCUYO. 2015.47(1): 193-208. ISSN Impreso 0370-4661. ISSN (en linea)1853-8665. http://repositorio.uchile.cl/handle/2250/135698

3. FAO. 2019. Major Tropical Fruits-Statistical Compendium. Rome.

4. BPS. 2021. Statistics Indonesia. Central Bureau ofStatistics. Indonesia.

5. Saragih. Bungaran. (2001). Voice from Bogor: BuildingAgribusiness System. Yayasan USESE - Sucofindo. Bogor

6. Suryantini N A. et.al. 2017. Analysis of Determination of Superior Fruit Commodities in Sigi Districts. Agrotekbis Journal. 5(4) : 518-524. Agustus 2017.

7. Syahroni. Muhammad. 2005. Strategy Analysis of Agribusiness Leading Commodities Development in Dompu Districts, West Nusa Tenggara Province. Thesis of Master's Degree Program in Management and Business IPB.

8. Arikunto, Suharsimi. 2010. Research Procedure : APractical Approach. Jakarta : Rineka Cipta

9. Bachrein S. 2003. Determination of Prominent Commodities of the Provinces. BP2TP Working Paper. Bogor : Center for the Assessment and Development of Agricultural Technology 
10. Saputri. I. \& A. Boedi. (2018). Analysis of Superior Economic Sector in Districts/cities in South Sumatra Province. Ilmu Ekonomi Journal. Volume 2 No 2 2018.

11. Tarigan. Robinson. 2012. Regional Economics: Theory and Application. Revision Edition. Jakarta: PT Bumi Aksara 